Thorax (1965), 20, 469.

\title{
Fibrous network of the lung and its change with age ${ }^{1}$
}

\author{
JOHNA. PIERCE AND RICHARD V. EBERT \\ From the Department of Medicine, University of Arkansas Medical Center, Little Rock, Arkansas
}

The remarkable elastic behaviour of the lung entails both continuous tissue stress and a cyclic stress produced by the fluctuating difference between intrathoracic and intra-alveolar pressures throughout the entire span of life. In spite of these potentially disruptive forces, lung structure is preserved by the fibrous connective-tissue proteinscollagen, elastin, and reticulin. These extracellular proteins are characterized by their insolubility, resistance to destruction, and high tensile strength. Collagen and elastin both exhibit elastic behaviour, but great extensibility is a property only of elastin. The most reasonable assumption is that the elastic fibres, therefore, are principally responsible for the elastic behaviour of the lung tissue, but sure proof is lacking.

Recently, Carton, Dainauskas, Tews, and Hass (1960) and Wright (1961) have described the nature of the network of elastic tissue in the lung. We sought to describe more fully the roles of collagenous and elastic fibres in the terminal air spaces of the lung, and thus their respective contributions to tissue elasticity and the general elastic performance of the lung. As the study developed, it seemed important to measure the amounts of collagen and elastin in the lung parenchyma and pleura. These findings have been correlated with the age of the subjects and interpreted according to knowledge about tissue elasticity.

\section{METHODS}

The study was based on 36 human lungs taken from patients who had died of a variety of diseases. No lungs were taken from patients with a history of cough, sputum production, dyspnoea, or chronic pulmonary disease, or from patients whose clinical history was incomplete. Of these 36, 27 lungs were dried in an inflated state by the extraction process using dilute $(0 \cdot 1 \mathrm{~N})$ sodium hydroxide solution (Pierce, Hocott, and Ebert, 1959). Nine more lungs were also dried in the inflated state but were fixed with formalin vapour. The advantage of the alkaline extraction method is that it permits the morphology of the lung

1 Supported in part by grants HTS5333 and HEO4031 from the U.S. Public Health Service to be examined and also the quantities of collagen and elastin to be measured.

The lungs were cut into thin slices and examined grossly and with a stereomicroscope. Slices of tissue were variously stained (Lillie, 1954) but not embedded. Elastic tissue was stained by the Taenzer-Unna acidorcein method (in absolute ethanol); Van Gieson's picric acid-acid fuchsin mixture was used to stain collagen ; and Fraenkel's method of using orcein and indigo-carmine was employed to stain both collagen and elastin in the same slice. All slices were rapidly dehydrated in alcohol and then in ether, and dried in vacuo to prevent collapse. This procedure enabled one to study the structure of the alveoli, alveolar ducts, and respiratory bronchioles as well as to visualize the relationship of the fibres in three dimensions. Preparations extracted with sodium hydroxide provided a more clearly defined fibrous network than did the formalin-vapour preparations.

Thin slices of the alkali-prepared lung tissue were dissected under the stereomicroscope, and the large blood vessels, bronchi, septa, and pleura were removed from the walls of the alveoli, alveolar ducts, and respiratory bronchioles. It was impossible to remove all vessels less than 50 microns in diameter completely, but all non-respiratory bronchioles and all vessels greater than 50 microns in diameter were entirely removed. The final preparations consisted of only the walls of the parenchymal air spaces together with very small vessels. Approximately $200 \mathrm{mg}$. of this light fluffy material was used for analysis.

Collagen and elastin were measured by the method of Lowry, Gilligan, and Katersky (1941). Since the entire lung had been exposed to sodium hydroxide solution for several days, the samples were immersed initially in $0 \cdot 1 \mathrm{~N}$ sodium hydroxide solution for only two hours at room temperature. The samples were then neutralized with hydrochloric acid, washed free of chloride, and put in an autoclave in water for six hours at 30 p.s.i. to hydrolyse collagen to gelatin. The insoluble residue was washed with water, and gelatin was recovered from the solution by evaporation. Crude elastin was prepared by treating the residue from the autoclaved sample with $0.1 \mathrm{~N}$ sodium hydroxide for $30 \mathrm{~min}$. at $100^{\circ} \mathrm{C}$. After washing, the material was dried in a vacuum desiccator. The crude elastin was corrected for impurity on the basis of nitrogen analyses (Dumas) performed in duplicate. The mean difference between the duplicate results was $0 \cdot 8 \%$. 
Elastin from human lungs was assumed to contain the same amount of nitrogen as elastin prepared from the ox neck ligament by the alkaline extraction method. We analysed seven samples of ox elastin and found $17 \cdot 2 \pm 0 \cdot 3 \%$ nitrogen, when corrected for ash $(0 \cdot 17 \%)$. Gelatin, prepared from ox-tendon collagen by treatment in the autoclave in water for six hours at 30 p.s.i., contained $18 \cdot 1 \%$ nitrogen. Nitrogen analyses determined the mean purity of 10 randomly selected samples of lung gelatin to be $95.4 \%$ Accordingly, the dry weight of the recovered gelatin has been reported as the figure for lung collagen.

\section{RESULTS}

DESCRIPTION OF LUNG SPECIMENS Cross-sections of the normal lung presented regularly-shaped spaces varying from 100 to 350 microns in diameter. The smaller spaces (100-200 microns) were the alveoli and the larger (250-350 microns) the alveolar ducts. The alveoli were not spherical but polygonal.

The relation between the alveoli and the alveolar ducts was clearly defined in those specimens in which the elastic tissue was stained (see Fig. 1). 음 Heavy bands of elastic tissue extended along the $\frac{\bar{\sigma}}{\bar{D}}$ axes of the alveolar ducts and respiratory $\frac{\text { }}{\sigma}$ bronchioles. The stereoscopic microscope gave a $\varrho$ three-dimensional view of the arrangement in the $\%$ wall of the respiratory bronchioles and alveolar $\overrightarrow{0}$ ducts. A heavy band of elastic tissue helically encircled each duct at the free edge of the lung $\vec{\omega}$ parenchyma. The respiratory bronchioles and ducts branch at least every 500 microns along their $\vec{x}$ axes, and where they branch the helical fibres at $N$ the leading edge of the respiratory surface also or branched. These heavy fibres in the helix con- $\vec{D}$ tinuously encircle the mouths of the alveoli. A 6 mesh of fine elastic fibres appears also in the $\mathrm{O}$ alveolar septa. Since these relationships are diffi- $\vec{c}$ cult to visualize in photographs, a drawing has $\mathbb{D}$ been reproduced (Fig. 2).

Interestingly enough, specimens stained for $\stackrel{\mathbb{D}}{3}$ collagen showed exactly the same arrangement of $\underset{\mathbb{D}}{ }$ fibres (Fig. 3) as the specimens stained for elastic tissue. Clearly, the collagen and elastic fibres are $\mathscr{\mathscr { O }}$ intimately associated in the structure of the of

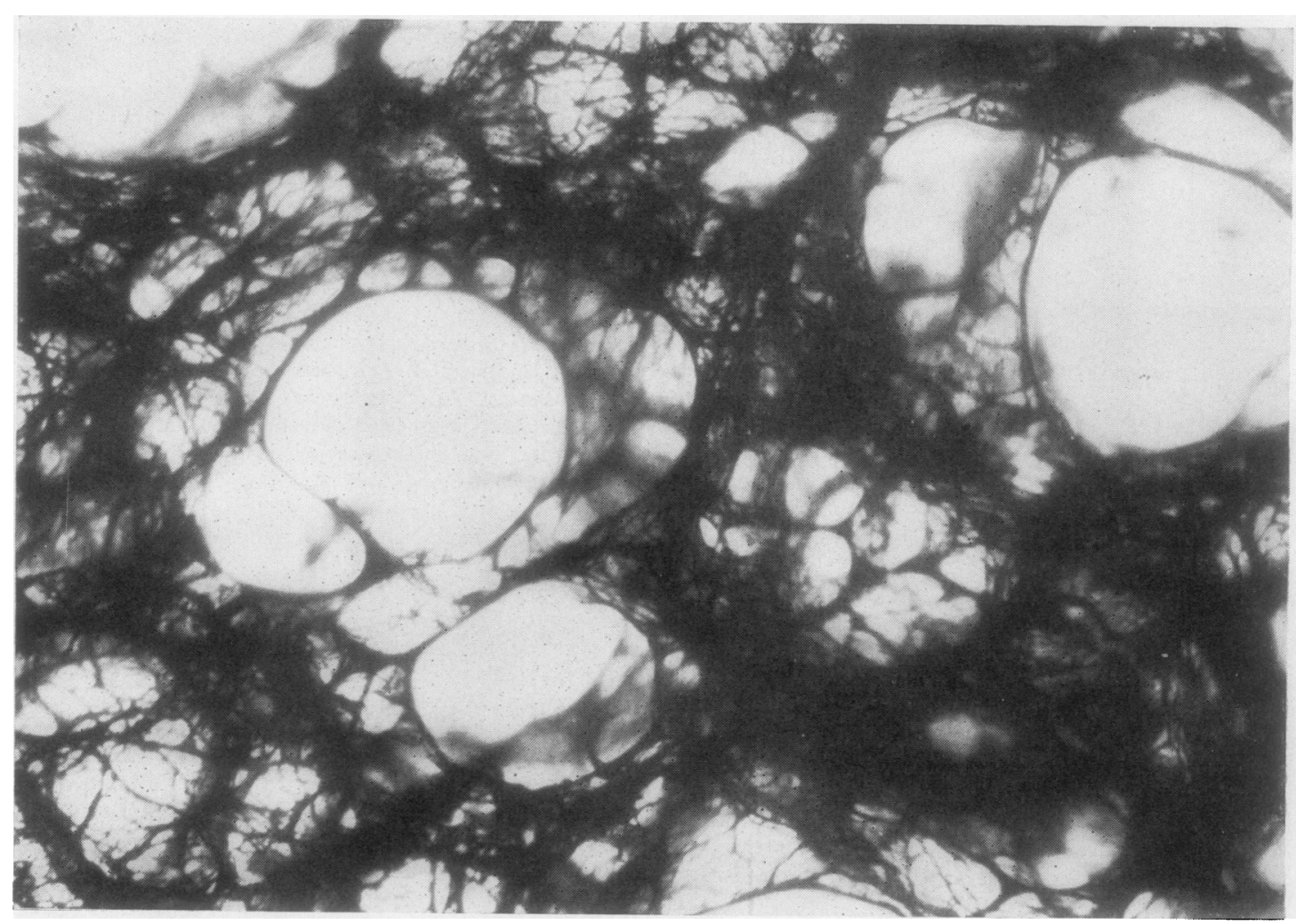

FIG. 1. Normal human lung prepared by alkaline extraction and stained for elastic tissue. 


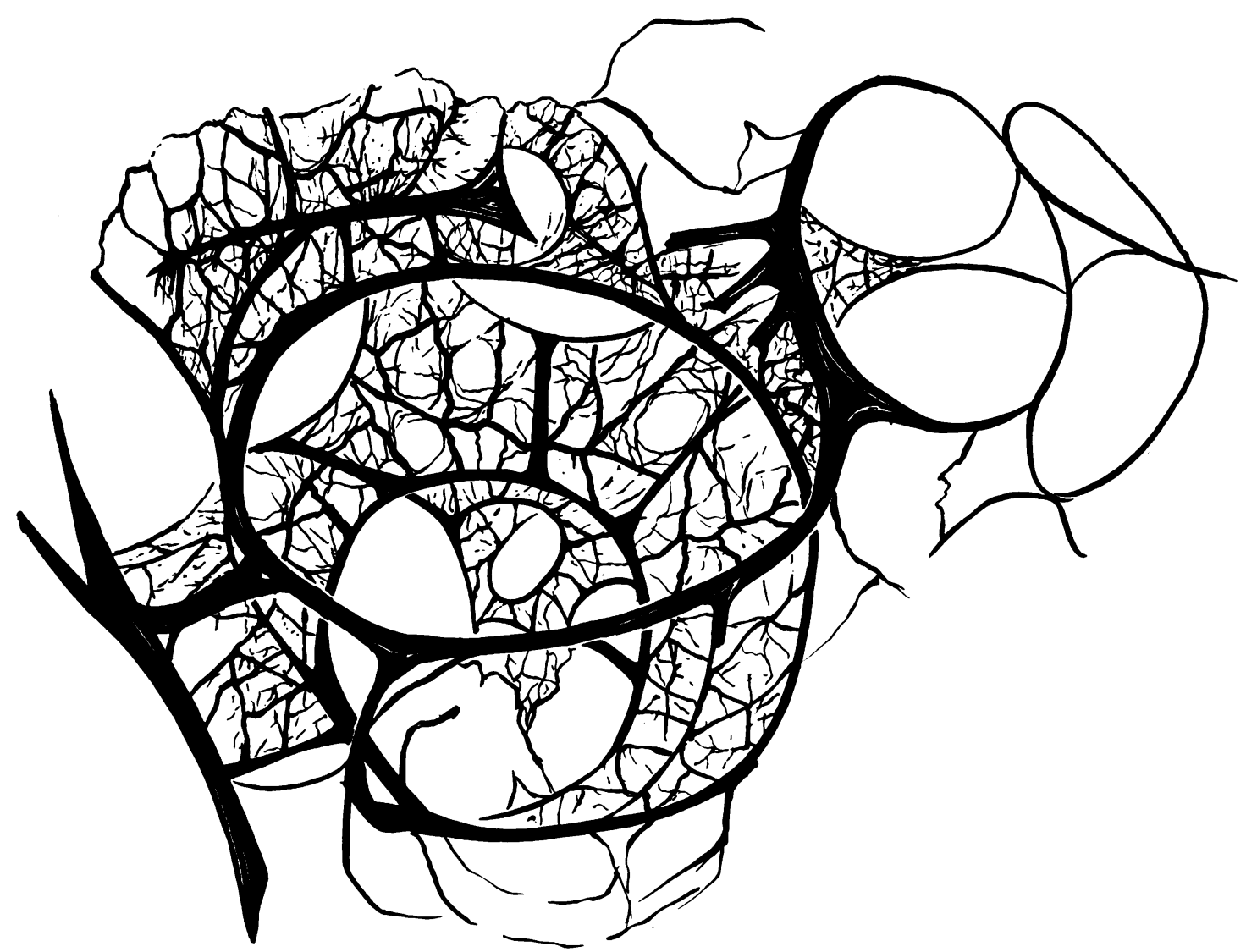

FIG. 2. Artist's sketch of the elastic fibres in the parenchyma of a human lung.

alveolar ducts and in the walls of the alveoli. It is possible, therefore, that the elastic fibres of the lung undergo little or no appreciable load extension during life. ${ }^{1}$

Even though none of the lungs came from patients who had a history of chronic respiratory disease, many of them exhibited areas of emphysema. In its mildest form, this consisted simply of dilated air spaces measuring between 0.5 and $1.0 \mathrm{~mm}$. in diameter (class 1). Many lungs showed even larger air spaces with evident loss of septa and multiple fenestrations in the remaining septa. If this condition involved less than $10 \%$ of the lung, it was considered mild (class 2 ), and if more than $10 \%$, moderate (class 3 ). No instance of advanced emphysema was observed, but both

\footnotetext{
1 We believe the specificity of the orcein stain for elastic tissue is reasonably good. Inasmuch as we did not prove this, we did not feel justified in discussing any possible increase in stainable elastic tissue in the pleura of aged as compared with young subjects.
}

centrilobular and panlobular emphysema were encountered. Table $I$, which relates the presence and degree of emphysema to age and sex, shows that emphysema was most common in elderly men.

T A B LE I

EMFHYSEMA OF 36 INFLATED LUNGS

\begin{tabular}{|c|c|c|c|c|c|c|c|c|c|}
\hline \multirow{2}{*}{\multicolumn{2}{|c|}{$\underset{\text { (years) }}{\text { Age }}$}} & \multicolumn{2}{|c|}{ None } & \multicolumn{2}{|c|}{ Class 11} & \multicolumn{2}{|c|}{ Class 2} & \multicolumn{2}{|c|}{ Class 3} \\
\hline & & $\mathbf{M}$ & F & $\mathbf{M}$ & $\mathbf{F}$ & $\mathbf{M}$ & $\mathbf{F}$ & $\mathbf{M}$ & $\mathbf{F}$ \\
\hline $\begin{array}{ll}\text { Under }_{41} & \\
41-50 & \ldots \\
51-60 & \ldots \\
61-70 & \ldots \\
\text { Over } 70 & \ldots\end{array}$ & $\begin{array}{l}. . \\
\cdots \\
\cdots\end{array}$ & $\begin{array}{l}1 \\
4 \\
2 \\
1 \\
1\end{array}$ & $\begin{array}{l}2 \\
1 \\
1 \\
2\end{array}$ & $\begin{array}{l}2 \\
3 \\
1\end{array}$ & 1 & $\begin{array}{l}1 \\
1 \\
4\end{array}$ & i & $\begin{array}{l}2 \\
3\end{array}$ & \\
\hline Total & . & 9 & 6 & 6 & 1 & 6 & 3 & 5 & 0 \\
\hline
\end{tabular}

${ }^{1}$ Class 1 reflects simple dilatation of air sacs; class 2 is destructive emphysema involving less than 10\% of the lung; and class 3 is involvement of more than $10 \%$, but less than $30 \%$, of the lung. 




FIG. 3. Normal human lung prepared by alkaline extraction and stained for collagen.

CHEMISTRY OF THE LUNG The results of chemical analysis for collagen and elastin appear in Tables II and III. Figure 4 illustrates the striking disparity between aged and young subjects in respect of the pleura. The ratio of collagen to elastin in the pleura decreased markedly from the young to the old subjects, whereas in the parenchymal samples it was not significantly different between young and old. These data show that the age-related increase in total lung elastin occurs mainly in the pleurae and the septa and not in the respiratory parenchyma. Table III presents the data on four of the subjects from whom duplicate slices of lung, as well as bronchi and pulmonary vessels, were analysed. The results of the duplicate lung samples are very nearly alike.

\section{DISCUSSION}

The present study, as well as earlier work (Orsós, 1907 ; von Hayek, 1960 ; Carton et al., 1960 ; and Wright, 1961), demonstrates that the terminal air spaces of the lung are surrounded and supported by a network of elastic tissue which, being continuous, ensures that applied forces will be transmitted equally to all parts of the lung. The elastic tissue is most prominent about the alveolar ducts and at the mouths of the alveoli. But collagen 
T A B LE II

COLLAGEN AND ELASTIN

\begin{tabular}{|c|c|c|c|c|c|c|c|}
\hline Case $^{1}$ & $\underset{\text { (years) }}{\text { Age }}$ & $\begin{array}{c}\text { Sample } \\
\text { (mg. dry } \\
\text { weight) }\end{array}$ & $\underset{(\%)}{\text { Collagen }}$ & $\underset{(\%)}{\text { Elastin }}$ & C. E Ratio & $\begin{array}{c}\text { Crude } \\
\text { Elastin } \\
\text { Residue } \\
\text { Purity } \\
(\%)\end{array}$ & Diagnosis \\
\hline $\begin{array}{c}\text { A. Parenc } \\
1 \\
2 \\
3 \\
4 \\
5 \\
6 \\
7 \\
8 \\
9 \\
10 \\
11 \\
12 \\
13 \\
14 \\
15 \\
16 \\
17 \\
18\end{array}$ & $\begin{array}{r}a \\
13 \\
14 \\
14 \\
15 \\
17 \\
18 \\
23 \\
26 \\
28 \\
46 \\
57 \\
65 \\
70 \\
70 \\
72 \\
73 \\
73 \\
76\end{array}$ & $\begin{array}{l}172 \\
171 \\
189 \\
173 \\
326 \\
168 \\
166 \\
165 \\
179 \\
172 \\
173 \\
289 \\
195 \\
179 \\
182 \\
169 \\
179 \\
243\end{array}$ & $\begin{array}{l}64 \cdot 5 \\
66.6 \\
48 \cdot 8 \\
55 \cdot 0 \\
58 \cdot 7 \\
63.7 \\
60.6 \\
62.7 \\
42 \cdot 7 \\
63.5 \\
50 \cdot 7 \\
52 \cdot 8 \\
44 \cdot 2 \\
50.3 \\
52.2 \\
48.3 \\
63.9 \\
40.9\end{array}$ & $\begin{array}{l}21.6 \\
23.7 \\
16.8 \\
26.5 \\
20.5 \\
27.9 \\
25.0 \\
25.3 \\
24 \cdot 1 \\
22 \cdot 8 \\
33.7 \\
15.9 \\
33.9 \\
33.7 \\
39 \cdot 8 \\
40.5 \\
26.0 \\
18.7\end{array}$ & $\begin{array}{l}2.99 \\
2.81 \\
2.90 \\
2.08 \\
2.86 \\
2 \cdot 28 \\
2.42 \\
2.48 \\
1.77 \\
2.79 \\
1.50 \\
3.32 \\
1.30 \\
1.49 \\
1.31 \\
1.19 \\
2.46 \\
2.19\end{array}$ & $\begin{array}{l}89 \cdot 7 \\
88 \cdot 4 \\
90 \cdot 3 \\
77 \cdot 6 \\
89 \cdot 9 \\
86 \cdot 3 \\
84 \cdot 5 \\
91 \cdot 8 \\
86 \cdot 7 \\
87 \cdot 7 \\
86 \cdot 8 \\
81 \cdot 1 \\
88 \cdot 7 \\
86 \cdot 3 \\
87 \cdot 7 \\
90 \cdot 9 \\
87 \cdot 4 \\
77 \cdot 4\end{array}$ & $\begin{array}{l}\text { Subarachnoid hacmorrhage } \\
\text { Acute peritonitis } \\
\text { Multiple contusions } \\
\text { Acute myelogenous leukaemia } \\
\text { Sudden death } \\
\text { Intracerebral haemorrhage; pregnancy } \\
\text { Ruptured ectopic pregnancy } \\
\text { Gunshot wound } \\
\text { Gunshot wound } \\
\text { Cerebral emboli; rheumatic heart disease } \\
\text { Subarachnoid haemorrhage } \\
\text { Bleeding oesophageal varices } \\
\text { Myocardial infarction } \\
\text { Calcific aortic stenosis } \\
\text { Coronary atherosclerosis } \\
\text { Carcinoma of pancreas } \\
\text { Myocardial infarction } \\
\text { Bleeding peptic ulcer }\end{array}$ \\
\hline $\begin{array}{c}\text { B. Pleura } \\
1 \\
2 \\
3 \\
4 \\
5 \\
6 \\
7 \\
8 \\
9 \\
10 \\
11 \\
12 \\
13 \\
14 \\
15 \\
16 \\
17 \\
18\end{array}$ & $\begin{array}{r}9 \\
13 \\
14 \\
15 \\
17 \\
18 \\
23 \\
26 \\
28 \\
46 \\
57 \\
65 \\
70 \\
70 \\
72 \\
73 \\
73 \\
76\end{array}$ & $\begin{array}{l}592 \\
304 \\
413 \\
561 \\
386 \\
425 \\
356 \\
287 \\
233 \\
599 \\
433 \\
444 \\
1,281 \\
341 \\
389 \\
365 \\
408 \\
268\end{array}$ & $\begin{array}{l}85 \cdot 1 \\
84 \cdot 9 \\
79 \cdot 8 \\
80 \cdot 9 \\
68 \cdot 1 \\
86 \cdot 5 \\
79 \cdot 3 \\
78 \cdot 5 \\
64 \cdot 1 \\
72 \cdot 1 \\
70 \cdot 5 \\
65 \cdot 9 \\
62 \cdot 2 \\
65 \cdot 3 \\
79 \cdot 5 \\
75 \cdot 0 \\
80 \cdot 9 \\
49 \cdot 5\end{array}$ & $\begin{array}{r}6 \cdot 6 \\
3 \cdot 7 \\
4 \cdot 9 \\
7 \cdot 9 \\
4 \cdot 5 \\
6 \cdot 4 \\
8 \cdot 5 \\
9 \cdot 1 \\
7 \cdot 7 \\
7 \cdot 3 \\
10 \cdot 0 \\
5 \cdot 3 \\
14 \cdot 9 \\
13 \cdot 7 \\
13 \cdot 9 \\
14 \cdot 6 \\
8 \cdot 5 \\
10 \cdot 2\end{array}$ & $\begin{array}{c}12.9 \\
27.9 \\
16 \cdot 3 \\
10 \cdot 2 \\
15 \cdot 1 \\
13 \cdot 5 \\
9.33 \\
8.63 \\
8 \cdot 32 \\
9 \cdot 88 \\
7 \cdot 05 \\
12.4 \\
4 \cdot 17 \\
4.77 \\
5 \cdot 72 \\
5 \cdot 14 \\
5.52 \\
4 \cdot 85\end{array}$ & $\begin{array}{l}91 \cdot 4 \\
83 \cdot 1 \\
84 \cdot 3 \\
77 \cdot 9 \\
70 \cdot 1 \\
75 \cdot 2 \\
79 \cdot 9 \\
80 \cdot 9 \\
81 \cdot 2 \\
57 \cdot 0 \\
81 \cdot 3 \\
57 \cdot 5 \\
65 \cdot 6 \\
64 \cdot 6 \\
84 \cdot 8 \\
80 \cdot 6 \\
73 \cdot 1 \\
62 \cdot 0\end{array}$ & \\
\hline
\end{tabular}

1 Cases $1,5,9,10,12$, and 13 were male; others were female.

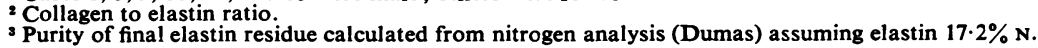

T A B L E III

COLLAGEN AND ELASTIN ANALYSES OF LUNG SLICES, BRONCHI, AND VESSEIS

\begin{tabular}{|c|c|c|c|c|c|c|}
\hline Case $^{2}$ & Part & $\begin{array}{c}\text { Sample } \\
\text { (mg. dry } \\
\text { weight) }\end{array}$ & $\begin{array}{c}\text { Col- } \\
\text { lagen } \\
(\%)\end{array}$ & $\underset{(\%)}{\text { Elastin }}$ & $\underset{\text { Ratio }}{\mathbf{C} \text { E }}$ & $\begin{array}{c}\text { Crude } \\
\text { Elastin } \\
\text { Residue } \\
\text { Purity } \\
(\%)\end{array}$ \\
\hline 3 & $\begin{array}{l}\text { Lung } \\
\text { slice } \\
\text { Bronchi } \\
\text { Vessels }\end{array}$ & $\begin{array}{l}255 \\
278 \\
264 \\
221\end{array}$ & $\begin{array}{l}73 \cdot 1 \\
68 \cdot 8 \\
82 \cdot 3 \\
81 \cdot 8\end{array}$ & $\begin{array}{r}17 \cdot 0 \\
17 \cdot 4 \\
3 \cdot 7 \\
7 \cdot 3\end{array}$ & $\begin{array}{r}4 \cdot 30 \\
3 \cdot 96 \\
22 \cdot 2 \\
11 \cdot 2\end{array}$ & $\begin{array}{l}94 \cdot 5 \\
94 \cdot 7 \\
90 \cdot 8 \\
82.9\end{array}$ \\
\hline 5 & 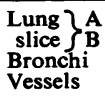 & $\begin{array}{l}557 \\
514 \\
647 \\
898\end{array}$ & $\begin{array}{l}62 \cdot 1 \\
62 \cdot 3 \\
61 \cdot 1 \\
47 \cdot 4\end{array}$ & $\begin{array}{r}18 \cdot 0 \\
21 \cdot 3 \\
5 \cdot 0 \\
12 \cdot 3\end{array}$ & $\begin{array}{c}3 \cdot 36 \\
2.92 \\
12 \cdot 3 \\
3 \cdot 86\end{array}$ & $\begin{array}{l}93 \cdot 7 \\
95 \cdot 8 \\
71 \cdot 7 \\
94 \cdot 1\end{array}$ \\
\hline 12 & $\begin{array}{l}\text { Lung } \\
\text { slice } \\
\text { Bronchi } \\
\text { Vessels }\end{array}$ & $\begin{array}{r}949 \\
914 \\
1,117 \\
1,077\end{array}$ & $\begin{array}{l}52.6 \\
58.6 \\
57.2 \\
43.7\end{array}$ & $\begin{array}{r}14 \cdot 3 \\
17 \cdot 6 \\
4 \cdot 8 \\
16 \cdot 3\end{array}$ & $\begin{array}{c}3.68 \\
3.33 \\
11.9 \\
2.68\end{array}$ & $\begin{array}{l}79.3 \\
76.6 \\
69.0 \\
92.6\end{array}$ \\
\hline 18 &  & $\begin{array}{l}744 \\
771 \\
598 \\
256\end{array}$ & $\begin{array}{l}51 \cdot 3 \\
40 \cdot 8 \\
34 \cdot 8 \\
48 \cdot 2\end{array}$ & $\begin{array}{r}20 \cdot 4 \\
14 \cdot 1 \\
4 \cdot 5 \\
14 \cdot 1\end{array}$ & $\begin{array}{l}2 \cdot 52 \\
2 \cdot 89 \\
7 \cdot 73 \\
3 \cdot 42\end{array}$ & $\begin{array}{l}85 \cdot 4 \\
76 \cdot 9 \\
16 \cdot 8^{2} \\
82 \cdot 3\end{array}$ \\
\hline
\end{tabular}

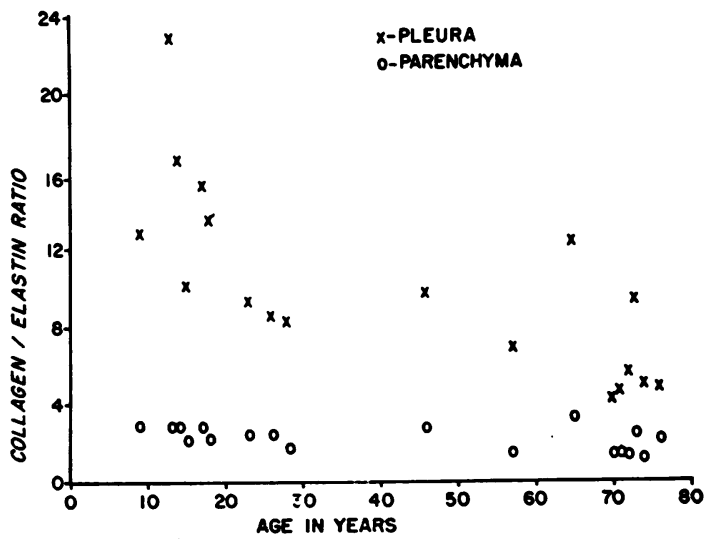

1 Lung sectioned to include pleura, bronchi, and vessels.

Subject numbers same as in Table II.

- Final residue contained inorganic calcium salts.

G. 4. Ratio of collagen to elastin plotted against age. 
fibres are disposed in a manner similar to, if not identical with, the elastic fibres, as Orsós (1907) noted. Policard (1955), on the other hand, described collagen about the alveolar ducts and mouths of the alveoli but held that these fibres were practically absent in the alveolar walls. Electron photomicrographs of the alveolar walls, however, do show frequent collagenous fibres intimately associated with the elastic tissue about the alveoli (Low, 1953). Reticulin fibres, which are abundant in the walls of the alveoli, are a form of collagen and exhibit the periodicity at approximately $640 \AA$, characteristic of collagen. All the evidence argues that elastic and collagenous fibres are mutually associated throughout the terminal air spaces in the lungs.

This close association of collagenous with elastic fibres, and the high ratio of collagen to elastin, do not support the usual description of the mechanics of elasticity in the lung. The common theory is that axial elongation of elastic fibres accounts for the elasticity of the lung, and many experiments have led towards or from that assumption. Elastin has a large range of extensibility, a low modulus of elasticity, and exhibits ideal elastic behaviour (Meyer and Ferri, 1936; Wöhlisch, Weitnauer, Grüning, and Rohrbach, 1943) without crystallization at any elongation (Hoeve and Flory, 1958). The total elastic performance of the airfilled lung, however, cannot be accounted for by elastic tissue, although occasionally this has been inferred (Lawton and Joslin, 1951). Obliteration of the important air-liquid interface by filling the lung with liquid demonstrates that tissue elasticity accounts for only one-fourth to one-third of the total retractive force observed in air-filled lungs. Recent studies on lung tissue elasticity (Radford, 1957 ; Carton, Clark, Dainauskas, and Barron, 1964) assume that elastic fibres undergo axial elongation as the lung is distended. Sternberg (1925) pointed out that there is no proof that this occurs, and no reason to take it for granted.

Collagen has a high tensile strength, a short range of extensibility, and a high modulus of elasticity. Since the collagenous and elastic fibres are intimately bound together in a similar course about the alveolar ducts, it does not seem likely that elastic behaviour is the product of axial elongation of the elastic tissue. Were that the case, the collagenous fibres would limit distension of the lungs. Orsós (1907) and von Hayek (1960) described these collagenous fibres as wavy bundles which could be straightened out while the elastic fibres were being extended, and Setnikar (1955) devised a theory to account for such complex tissue elasticity. We made our study in lungs dried in the inflated state and did not observe any curling or waviness of collagenous fibres, but rather the spiral formations already described.

The spiral arrangement of closely associated collagenous and elastic fibres lends itself, however, to another explanation of tissue elasticity of the lung. Wright (1961) and Vincent, Mitchell, Filley, Dart, Harris, Wagner, Petty, and Ryan (1964) mentioned a helical distribution of the elastic fibres about the alveolar ducts. Oderr (1964) emphasized the importance of these helical fibres and noted that the alveoli are radially arranged about the alveolar duct and open as the helix expands. Our observations are similar to those of Oderr. In a structure of this sort, the elasticity would be similar to that of a coiled spring, dependent on shearing stress rather than axial stretch of the fibres. This means that the lung expands by unfolding its structure with the extension of the ductal helices. This uncoiling of the helices produces torsion or twisting in the tissue fibres which leads to elastic performance as the fibres tend to recover from this deformation. The elastic behaviour of the pleura and the septa can also be interpreted as a function of the arrangement, or weave, of the collagenous and elastic fibres. A tissue composed of relatively inextensible fibrous elements may exhibit elastic behaviour. The most familiar example of this is the dermal layer of the skin, composed almost entirely of collagen, and it is also notable that the elastic pleurae in lungs from young patients used in this study contained roughly nine times more collagen than elastin.

Previous studies demonstrate that the collagen content of the whole lung remains constant with advancing age, but that elastin increases significantly (Pierce and Hocott, 1960 ; Pierce, 1964). This increase of elastin with age has been confirmed by several other investigators (Briscoe and Loring, 1958 ; Scarselli, and Repetto, 1959 ; Wright, Kleinerman, and Zorn, 1960 ; FitzPatrick and Hospelhorn, 1962). It has also been shown that emphysematous lungs have normal amounts of collagen and elastin (Pierce, Hocott, and Ebert, 1961). This study reveals that the ratio of collagen to elastin in the walls of the terminal air spaces remains approximately the same at all ages. Elastin increases with age in the interlobular septa, the pleura, and perhaps in the bronchi and vessels. This distinction will probably affect the understanding of lung tissue elastic performance. Bunting (1939) observed that immobile scars had few elastic fibres but that scars involving the myocardium, pericardium or pleura had numerous 
elastic fibres. He noted that those fibres in adhesions were parallel to the lines of tension, and proposed that rhythmic stress might stimulate the development of elastic tissue fibres. Dyson and Decker (1958) made a similar suggestion in their study of the characteristic association of elastosis with fluctuating or rhythmic stress. There is no reason to doubt these observations although, to our knowledge, the suggestion has not been confirmed in experimental animals. If, indeed, rhythmic stress promotes the formation of elastic tissue, then one should expect the pleura, the interlobular septa, and the bronchi to accumulate elastic fibres with advancing age, since these structures necessarily transmit and distribute all forces between the chest wall and the lung. And, of course, the pleura undergoes maximal strain (elongation) with motion of the lung.

In the past, elastic tissue has been regarded as the most important structural tissue in the lung because of its elastic properties, its abundance in lung, and its strength. The results of this study lead us to maintain, on the contrary, that collagen is the most important material for maintaining the structural integrity of the lung, since it is present in larger amounts and has greater tensile strength than elastin; and, further, that the elastic behaviour of lung tissue results from secondary and tertiary structural considerations and not from the axial elongation of fibrous elements.

It has been observed recently that enlarged air spaces and destruction of septa resembling, in all ways, the pathological changes described in pulmonary emphysema appear in the lungs of most elderly men (Snider, Brody, and Doctor, 1962 ; Azcuy, Anderson, and Foraker, 1962 ; Thurlbeck, 1963 ; and Wyatt, Fischer, and Sweet, 1964). Our study also demonstrates that these lesions are found more commonly in men than in women, and that they increase in prevalence with increasing age. The presence of these lesions implies that the fibrous network of the lung disintegrates with advancing age. Why the structure of the lung is commonly altered in old age in spite of the great strength lent to it by the collagen network is at present a mystery.

\section{SUMMARY}

The fibrous network of the lung was studied in 36 lungs from subjects free of symptoms of respiratory disease. The helical arrangement and the intimate association of collagenous and elastic fibres in the respiratory bronchioles and alveolar ducts argue that lung-tissue elastic behaviour results from an unfolding of the lung structure, and not, as previously supposed, from the axial elongation of elastic tissue fibres. This viewpoint was supported by chemical tests which revealed twice as much collagen as elastin in the respiratory parenchyma. The age-related increase of lung elastin occurs in the pleura and septa, perhaps in the bronchi and vessels, but not in the respiratory parenchyma. These findings are consistent with the idea that rhythmic stress promotes the formation of elastic tissue. Destructive emphysema of moderate severity frequently appeared in the lungs of elderly men. We suggest that the collagenous fibres are the most important components of the fibrous network of the lung since they are more abundant and have greater tensile strength than the other components. Lung collagen deserves more consideration than it has received in the past.

The authors wish to express appreciation to Messrs. Robert Kordsmeier and Wilbur Giles for expert technical assistance.

\section{REFERENCES}

Azcuy, A., Anderson, A. E., Jr., and Foraker, A. G. (1962). The morphological spectrum of aging and emphysematous lungs. Ann. intern. Med., 57, 1.

Briscoe, A. M., and Loring, W. E. (1958). Elastin content of the human lung. Proc. Soc. exp. Biol. (N.Y.), 99, 162.

Bunting, C. H. (1939). New formation of elastic tissue in adhesions between serous membranes and in myocardial scars. Arch. Path., 28, 306 .

Carton, R. W., Clark, J. W., Dainauskas, J., and Barron, A. (1964). Estimation of tissue elasticity of the lung. J.appl. Physiol., 19, 236. Dainauskas, J. Tews, B., and Hass, G. M. (1960). Isolation and study of the elastic tissue network of the lung in three dimensions. Amer. Rev. resp. Dis., 82, 186.

Dyson, B. C., and Decker, J. P. (1958). Endocardial fibroelastosis in the adult. Arch. Path., 66, 190.

FitzPatrick, M., and Hospelhorn, V. D. (1962). Studies on human pulmonary connective tissue. 1. Amino acid composition of elastins isolated by alkaline digestion. J. Lab. clin. Med., 60, 799.

Hoeve, C. A. J., and Flory, P. J. (1958). The elastic properties of elastin. J. Amer. chem. Soc., 80, 6523.

Lawton, R. W., and Joslin, D. (1951). Measurements on the elasticity of the isolated rat lung. Amer. J. Physiol., 167, 111.

Lillie, R. D. (1954). Histopathologic Technic and Practical Histochemistry, pp. 346, 360. Blakiston, New York.

Low, F. N. (1953). The pulmonary alveolar epithelium of laboratory mammals and man. Anat. Rec., 117, 241.

Lowry, O. H., Gilligan, D. R., and Katersky, E. M. (1941). The determination of collagen and elastin in tissues, with results obtained in various normal tissues from different species. J. biol. Chem., 139, 795.

Meyer, K. H., and Ferri, C. (1936). Die elastischen Eigenschaften der elastischen und der kollagenen Fasern und ihre molekulare Deutung. Pfü̈gers Arch. ges. Physiol., 238, 78.

Oderr, C. (1964). Architecture of the lung parenchyma. Studies with a specially designed $x$-ray microscope. Amer. Rev. resp. Dis., 90, 401 .

Orsós, F. (1907). Utber das elastische Gerüst der normalen und der emphysematösen Lunge. Beitr. path. Anat., 41, 95.

Fierce, J. A. (1964). Biochemistry of aging in the lung. In Cander, L., and Moyer, J. H., Aging of the Lung, p. 61. Grune and Stration, New York and London.

and Hocott, J. B. (1960). Studies on the collagen and elastin content of the human lung. J. clin. Invest., 39, 8. - and Ebert, R.V. (1959). Studies of lung collagen and elastin. Amer. Rev. resp. Dis., 80, no. 1, part 2, p. 45.

(1961). The collagen and elastin content of the lung in emphysema. Ann. intern. Med., 55, 210. 
Policard, A. (1955). Le Poumon: Structures et Mécanismes à l'État Normal et Pathologique, p. 22. Masson, Paris.

Radford, E. P., Jr. (1957). Recent studies of mechanical properties of mammalian lungs. In Tissue Elasticity, ed. Remington, J. W., p. 177. [American Physiological Society] Waverly Press, Baltimore.

Scarselli, V., and Repetto, M. (1959). The elastin content of lung in relation to age. Ital. J. Biochem., 8, 169.

Setnikar, I. (1955). Origine e significato delle proprietà meccaniche del polmone. Arch. Fisiol., 55, 349.

Snider, G. L., Brody, J. S., and Dcctor, L. (1962). Subclinical pul monary emphysema, Amer. Rev. resp. Dis., 85, 666.

Sternberg, C. (1925). Uber die elastischen Fasern. Virchows Arch. Path. Anat., 254, 656.

Thurlbeck, W. M. (1963). The incidence of pulmonary emphysema Amer. Rev. resp. Dis., 87, 206.
Vincent, T. N., Mitchell, R. S., Filley, G. F., Dart, G. A., Harris, L. M., Wagner, W., Petty, T. L., and Ryan, S. F. (1964). Duct

ectasia. J. Lancet, 84, 331.
von Hayek, H. (1960). The Human Lung, trans. Krahl, V. E., p. 203. $\frac{\mathcal{D}}{\mathrm{D}}$ Hafner, New York.

Wöhlisch, E., Weitnauer, H., Grüning, W., and Rohrbach, R. (1943). Thermodynamische Analyse der Dehnung des elastischen Gewebes vom Standpunkt der statistisch-kinetischen Theorie der Kautschukelastizität. Kolloid-zeitschrift, 104, 14.

Wright, G. W., Kleinerman, J., and Zorn, E. M. (1960). The elastin ? and collagen content of normal and emphysematous human lungs. Amer. Rev. resp. Dis., 81, 938.

Wright, R. R. (1961). Elastic tissue of normal and emphysematous lungs. A tridimensional histologic study. Amer. J. Path., 39, 355.

Wyatt, J. P., Fischer, V. W., and Sweet, H. C. (1964). The pathomorphology of the emphysema complex, Part II. Amer. Rev. resp. Dis., 89, 721 . 